\title{
Advanced therapies in Eisenmenger syndrome
}

\author{
Heba Nashat, Andrew Constantine and Konstantinos Dimopoulos ${ }^{*}$ (i)
}

\begin{abstract}
Background: This is a case report of a patient diagnosed with Eisenmenger syndrome in adult life.

Case presentation: The patient had a large secundum atrial septal defect diagnosed incidentally in her twenties, with established pulmonary vascular disease and thus the defect was not closed. Over several years the patient showed signs of progressive disease with premature right ventricular dysfunction, preceding any significant symptomatic decline. Her medical therapy was escalated with the addition of intravenous epoprostenol, resulting in both objective and symptomatic improvement.

Conclusions: Early medical intervention and treatment can positively impact on the outcome of patients with pulmonary arterial hypertension associated with congenital heart disease.

Keywords: Congenital heart disease, Pulmonary arterial hypertension, Eisenmenger syndrome, Triple therapy, Epoprostenol
\end{abstract}

\section{Background}

Eisenmenger syndrome (ES) is the most severe form of pulmonary arterial hypertension (PAH) related to congenital heart disease (CHD). Systemic-to-pulmonary (leftto-right) shunting via a large pre or post-tricuspid defect can result in excess pressure and volume loading of the pulmonary vasculature and development of pulmonary vascular disease (PVD). Pulmonary arterial pressure can subsequently rise to near systemic levels resulting in shunt reversal (right-to-left) with chronic cyanosis and ES.

ES is a multisystem disorder associated with significant morbidity and mortality. Targeted pulmonary vasodilator therapy has been shown to be beneficial in various forms of PAH, in terms of functional status, disease progression and prognosis. Data supporting the use of PAH therapies in the ES cohort are limited. ES patients should be managed in centres that are experienced in both PAH and

\footnotetext{
* Correspondence: k.dimopoulos02@gmail.com

Adult Congenital Heart Centre and National Centre for Pulmonary Hypertension, National Heart and Lung Institute, Royal Brompton Hospital, Imperial College, Sydney Street, London SW3 6NP, UK
}

CHD as morbidity and mortality are the result of the $\mathrm{PAH}$, chronic cyanosis and the congenital heart defect [1].

We report the case of a patient with ES, in whom PAH therapy was gradually escalated with the aim of optimising not only functional status but also other markers of adverse outcome.

\section{Case presentation}

This 25-year-old female presented to a local hospital in her country of origin with breathlessness. An echocardiogram at the time confirmed a large secundum atrial septal defect (ASD) of maximum diameter $4.2 \mathrm{~cm}$ with bidirectional shunting. At the age of 28 years she was referred to a tertiary centre where she underwent right heart catheterisation, confirming severe PAH. As a result, ASD closure was contraindicated. She was commenced on a phosphodiesterase type 5 inhibitor, sildenafil, at a dose of $25 \mathrm{mg}$ three times a day. She remained stable and moved to the United Kingdom at the age of 30 years.

(c) The Author(s). 2020 Open Access This article is licensed under a Creative Commons Attribution 4.0 International License, which permits use, sharing, adaptation, distribution and reproduction in any medium or format, as long as you give appropriate credit to the original author(s) and the source, provide a link to the Creative Commons licence, and indicate if changes were made. The images or other third party material in this article are included in the article's Creative Commons licence, unless indicated otherwise in a credit line to the material. If material is not included in the article's Creative Commons licence and your intended use is not permitted by statutory regulation or exceeds the permitted use, you will need to obtain permission directly from the copyright holder. To view a copy of this licence, visit http://creativecommons.org/licenses/by/4.0/ The Creative Commons Public Domain Dedication waiver (http://creativecommons.org/publicdomain/zero/1.0/) applies to the data made available in this article, unless otherwise stated in a credit line to the data. 


\section{Investigations}

On presentation to our service, her resting oxygen saturation was $87 \%$ on air, with no differential cyanosis (similar oxygen saturations in the fingers and toes). She had a right ventricular lift with a normal first heart sound, and a mildly split-second heart sound with a loud pulmonary component. There was a grade $1 / 6$ pansystolic murmur at the left lower sternal border and no diastolic murmurs.

During the 6-min walk test she managed a distance (6MWD) of $385 \mathrm{~m}$. Peripheral oxygen saturation fell from 94 to $77 \%$ and the Borg dyspnoea score rose from 0 to 3 . At this time, she had a haemoglobin of $14.9 \mathrm{~g} / \mathrm{dL}$, platelets of $111 \times 10^{9} / \mathrm{L}$ and a b-type natriuretic peptide (BNP) level of $330 \mathrm{ng} / \mathrm{L}$ (normal < $20 \mathrm{ng} / \mathrm{L}$ ). She was iron deficient with transferrin saturation of $15 \%$ (normal 2045\%). Autoimmune, serology and virology screening were all negative. A chest radiograph showed mild thoracic scoliosis, markedly enlarged central pulmonary arteries with evidence of mural calcification, and mild cardiomegaly (Fig. 1).

The transthoracic echocardiogram confirmed a large secundum ASD (diameter $4.2 \mathrm{~cm}$ ) with bidirectional shunting at rest (Fig. 2). The left ventricle was small with a normal systolic function. The right ventricle (RV) was severely dilated with preserved longitudinal systolic function (tricuspid annular plane systolic excursion, TAPSE $2 \mathrm{~cm}$ ), but impaired radial function. RV systolic pressure was estimated at $94 \mathrm{mmHg}$. A computed

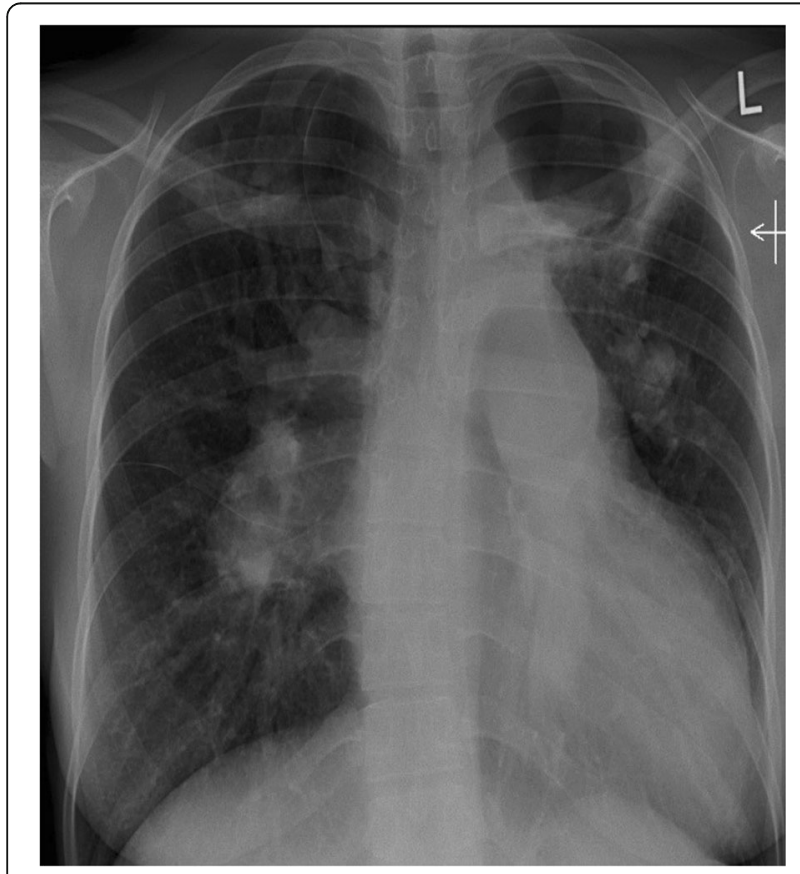

Fig. 1 Chest radiograph showing large pulmonary arteries and cardiomegaly

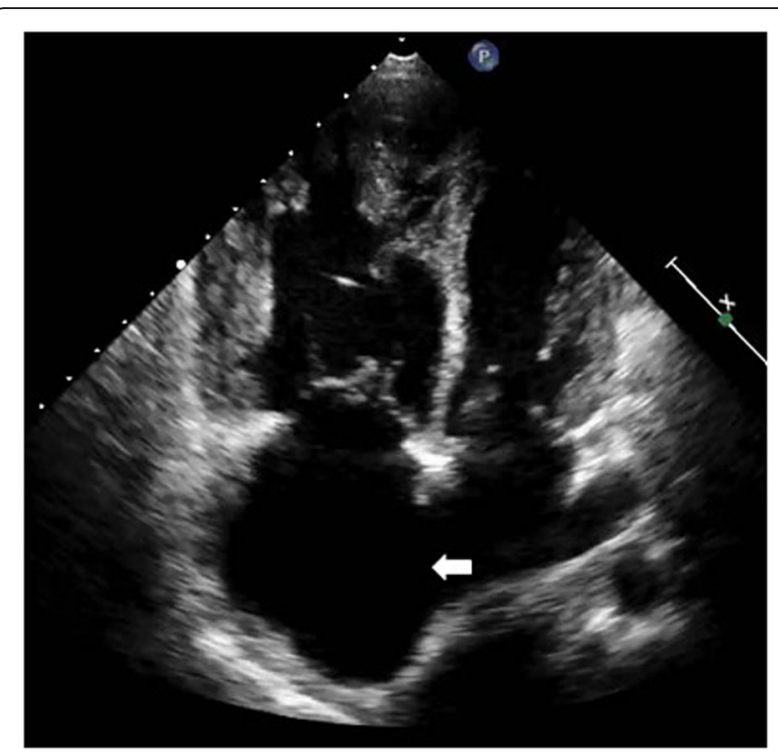

Fig. 2 Transthoracic echocardiogram demonstrating a 4-chamber view of the heart. The right atrium and ventricle are dilated, with a small underfilled left side. A large secundum type atrial septal defect is seen (arrow)

tomography pulmonary angiogram showed severely dilated central pulmonary arteries with extensive mural thrombus in both distal main pulmonary arteries (Fig. 3). At right heart catheterisation, mean pulmonary artery pressure was $69 \mathrm{mmHg}$, indexed pulmonary vascular resistance was $28 \mathrm{WU} \cdot \mathrm{m}^{2}$ and the ratio of pulmonary to systemic blood flow (Qp/Qs) was 0.8. There was no reversibility with nitric oxide.

\section{Management and follow-up}

Based on the investigations, and in the presence of severe PVD in the presence of unrepaired CHD and shunt reversal, the diagnosis of ES was made. Her medical

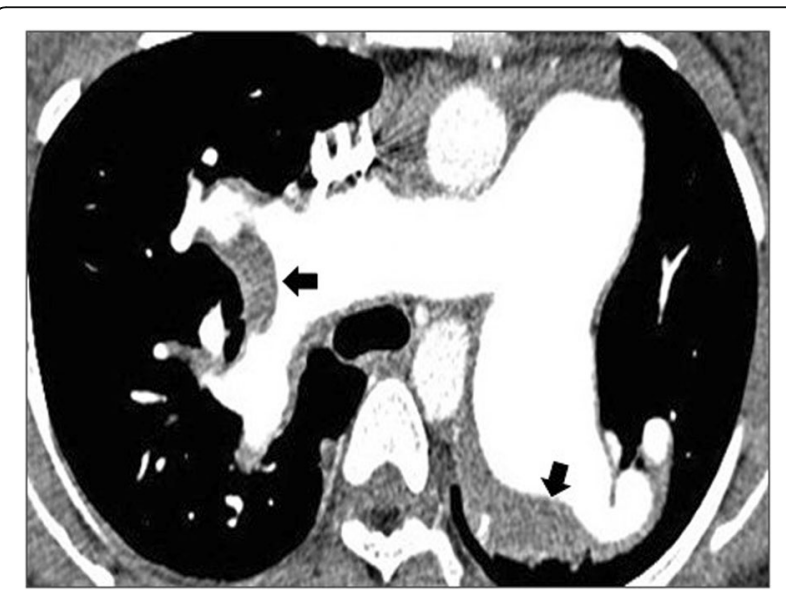

Fig. 3 Computed tomography of the pulmonary arteries illustrating severely dilated pulmonary arteries and in-situ thrombosis (arrows) 
treatment was escalated from monotherapy (sildenafil) to combination therapy, with the addition of bosentan (an endothelin receptor antagonist, ERA). She was also commenced on warfarin in view of the in situ pulmonary artery thrombosis. Following counselling about the significant risks of pregnancy and importance of adequate contraception, a progesterone implant was placed.

She remained clinically stable at regular follow-up visits with WHO functional class II breathlessness. However, a transthoracic echocardiogram at 5 years from the initial presentation showed worsening $\mathrm{RV}$ and right atrial dilatation and a reduction in RV function (TAPSE $1.1 \mathrm{~cm}$ ) despite maximum oral combination therapy. The BNP remained deranged at $310 \mathrm{ng} / \mathrm{L}$ and her $6 \mathrm{MWD}$ (385 m) was below target, and lower than expected for a young female with no co-morbidities. After discussion within the multidisciplinary team, we proceeded with escalation to triple therapy and she was commenced on intravenous epoprostenol. This triggered a referral for transplant assessment.

After slow up-titration of epoprostenol to a dose of 24 $\mathrm{ng} / \mathrm{kg} / \mathrm{min}$, improvements were seen in RV function (TAPSE $2.1 \mathrm{~cm}$ from $1.1 \mathrm{~cm}$ ), but with no reduction in RV size. 6MWD increased from 385 to $450 \mathrm{~m}$. Despite previously reporting few symptoms (graded as WHO functional class II), she now described a significant symptomatic improvement with epoprostenol, suggesting that she was previously underestimating her level of limitation. The BNP level fell from $310 \mathrm{ng} / \mathrm{L}$ to $100 \mathrm{ng} / \mathrm{L}$ (Fig. 4). Her clinical improvement was sustained at her most recent review 18 months from initiation of epoprostenol, without major complications or a decline in RV function.

\section{Discussion}

Patients with ES form a heterogenous group. The anatomical position of the shunt can influence outcome. Patients with pre-tricuspid defects, as in this case with an ASD, have been shown to have a worse outcome than those with post-tricuspid shunts [2, 3]. Indeed, they differ in terms of right ventricular pathophysiology and adaptation. The RV is typically dilated and is more often impaired than in patients with post-tricuspid shunts. Moreover, the right atrium is typically significantly dilated and moderate or severe tricuspid regurgitation is common. This "Eisenmenger ASD" phenotype, which resembles idiopathic $\mathrm{PAH}$, tends to be managed more aggressively by clinicians $[2,4]$.

Although better than in other forms of PAH, mortality remains high in ES. Registry and retrospective data have shown that, as well as improving exercise capacity and haemodynamic parameters, PAH therapies are likely to improve survival in this cohort [5-10]. Nevertheless, evidence based and consensus driven treatment algorithms for patients with ES are lacking. Monitoring and prognostication tools have been proposed and may contribute to the development of more robust treatment guidelines for this group [5, 11].

In the case presented, a patient with ES was initiated on triple combination therapy based on objective markers of a suboptimal response to therapy. Patients with CHD are known to underestimate their level of limitation due to chronic adaptation and objective measures of exercise intolerance, such as 6MWD, are recommended at each routine follow-up [12]. To date, there is no robust evidence supporting the use of combination PAH therapy in ES. In other forms of PAH, initial or early sequential double and triple PAH therapies are supported by evidence and expert opinion [13]. ES is a progressive life-threatening condition and aggressive treatment with $\mathrm{PAH}$ therapies should be considered, including combination therapy.

The literature on the use of intravenous prostanoids in ES is limited [14-18]. Moreover, concerns related to the risk of systemic infection and endocarditis related to the indwelling central catheter, potential embolic phenomena and reduced tolerability due to shunting of

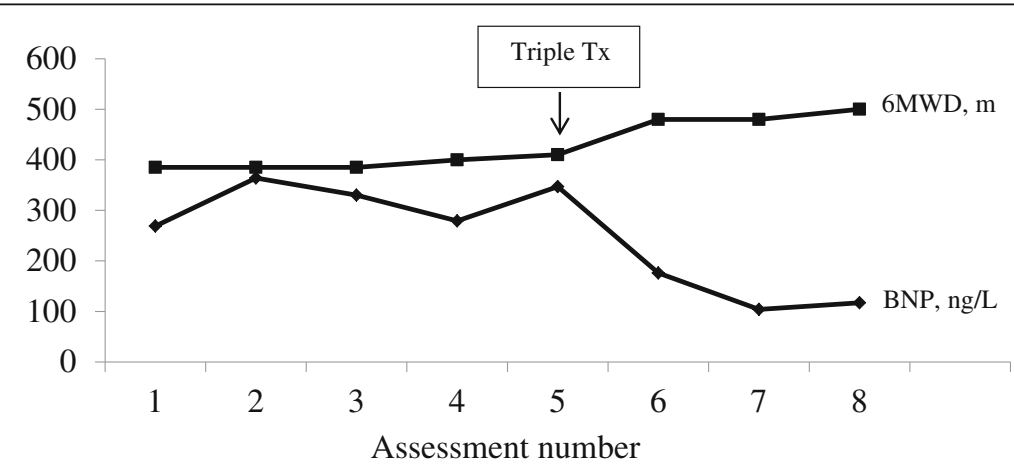

Fig. 4 6-min walk distance (6MWD) and b-type natriuretic peptide (BNP) over time. Note the improvement in both after initiation of triple pulmonary arterial hypertension therapy (Triple Tx), m, meters 
medication to the systemic circulation have discouraged physicians from using intravenous therapies in CHD patients with PAH. In our patient, intravenous therapy was well tolerated, with no significant complications. Moreover, there was a significant subjective and objective improvement in functional and prognostic parameters.

\section{Conclusions}

We submit that all ES patients should be monitored closely for evidence of disease progression, remembering that functional class and subjective description of symptoms are likely to underestimate the true level of limitation. Early double and triple combination therapy in this patient group are not supported by evidence but can prove to be beneficial in select patients with clear evidence of suboptimal response to treatment or disease progression. Care, expertise, patient engagement and education are required for the successful management of this complex group of patients.

\section{Abbreviations}

6MWD: 6-min walk distance; ASD: Atrial septal defect; BNP: B-type natriuretic peptide; CHD: Congenital heart disease; ERA: Endothelin receptor antagonist; ES: Eisenmenger syndrome; PAH: Pulmonary arterial hypertension; PVD: Pulmonary vascular disease; Qp/Qs: Pulmonary to systemic blood flow ratio; TAPSE: Tricuspid annular plane systolic excursion; WU: Wood units

\section{Acknowledgements}

Not applicable.

\section{About this supplement}

This article has been published as part of Journal of Congenital Cardiology Volume 4 Supplement 1 2020: Unmet needs in Pulmonary Hypertension associated with Adult Congenital Heart Disease (ACHD-PH). The full contents of the supplement are available at https://jcongenitalcardiology. biomedcentral.com/articles/supplements/volume-4-supplement-1

\section{Authors' contributions}

Authors HN, AC and KD contributed to the conception and planning of the case report. $\mathrm{HN}$ drafted the case report. $\mathrm{HN}, \mathrm{AC}$ and $\mathrm{KD}$ revised the report and finalised. $H N, A C$, and $K D$ approved the final manuscript for publication.

\section{Funding}

Medical writing support was provided by nspm Itd, Meggen, Switzerland. The manuscript was funded by a Medical and Educational Goods and Services (MEGS) grant and Actelion Pharmaceuticals UK Limited (who had no influence on manuscript writing).

\section{Availability of data and materials}

Not applicable.

\section{Ethics approval and consent to participate}

Informed consent was obtained for the patient to form the subject of this case report in line with CARE guidance. No special ethics approval was necessary for this case report.

\section{Consent for publication}

The patient gave consent for the their clinical details along with any identifying images to be published in this study.

\section{Competing interests}

Dr. Nashat has received a personal travel grant from Actelion Pharmaceuticals UK. Dr. Constantine has received a personal educational grant from Actelion Pharmaceuticals UK. Dr. Dimopoulos has received nonfinancial support from Actelion Pharmaceuticals; and has been a consultant to and received grants and personal fees from Actelion Pharmaceuticals, Pfizer, GlaxoSmithKline, and Bayer/MSD.

Received: 12 November 2020 Accepted: 12 November 2020 Published: 16 December 2020

\section{References}

1. Dimopoulos K, Wort SJ, Gatzoulis MA. Pulmonary hypertension related to congenital heart disease: a call for action. Eur Heart J. 2014;35:691-700. Available from. https://doi.org/10.1093/eurheartj/eht437.

2. Moceri P, Kempny A, Liodakis E, Alonso Gonzales R, Germanakis I, Diller G-P, et al. Physiological differences between various types of Eisenmenger syndrome and relation to outcome. Int J Cardiol. 2015;179:455-60. Available from. https://doi.org/10.1016/j.ijcard.2014.11.100.

3. Ramjug S, Hussain N, Hurdman J, Billings C, Charalampopoulos A, Elliot CA, et al. Pulmonary arterial hypertension associated with congenital heart disease: comparison of clinical and anatomic-pathophysiologic classification. J Heart Lung Transplant. 2016;35(5):610-8. Available from. https://doi.org/10. 1016/.healun.2015.12.016.

4. Hjortshøj CMS, Kempny A, Jensen AS, Sørensen K, Nagy E, Dellborg M, et al. Past and current cause-specific mortality in Eisenmenger syndrome. Eur Heart J. 2017;38(26):2060-7. Available from. https://doi.org/10.1093/ eurheartj/ehx201.

5. Diller G-P, Kempny A, Alonso-Gonzalez R, Swan L, Uebing A, Li W, et al. Survival prospects and circumstances of death in contemporary adult congenital heart disease patients under follow-up at a large tertiary Centre. Circulation. 2015;132(22):2118-25. Available from. https://doi.org/10.1161/ circulationaha.115.017202.

6. Dimopoulos K, Inuzuka R, Goletto S, Giannakoulas G, Swan L, Wort SJ, et al. Improved survival among patients with Eisenmenger syndrome receiving advanced therapy for pulmonary arterial hypertension. Circulation. 2010; 121(1):20-5. Available from. https://doi.org/10.1161/circulationaha.109. 883876

7. Galiè N, Beghetti M, Gatzoulis MA, Granton J, Berger RMF, Lauer A, et al. Bosentan therapy in patients with Eisenmenger syndrome: a multicenter, double-blind, randomized, placebo-controlled study. Circulation. 2006; 114(1):48-54. Available from. https://doi.org/10.1161/circulationaha.106. 630715.

8. Singh TP, Rohit M, Grover A, Malhotra S, Vijayvergiya R. A randomized, placebo-controlled, double-blind, crossover study to evaluate the efficacy of oral sildenafil therapy in severe pulmonary artery hypertension. Am Heart J. 2006;151(4):851.e1-5. Available from. https://doi.org/10.1016/j.ahj.2005.09. 006.

9. Mukhopadhyay S, Nathani S, Yusuf J, Shrimal D, Tyagi S. Clinical efficacy of phosphodiesterase-5 inhibitor tadalafil in Eisenmenger syndrome--a randomized, placebo-controlled, double-blind crossover study. Congenit Heart Dis. 2011;6(5):424-31. Available from. https://doi.org/10.1111/j.17470803.2011.00561.x

10. Berger RMF, Beghetti M, Galiè N, Gatzoulis MA, Granton J, Lauer A, et al. Atrial septal defects versus ventricular septal defects in BREATHE-5, a placebo-controlled study of pulmonary arterial hypertension related to Eisenmenger's syndrome: a subgroup analysis. Int J Cardiol. 2010;144(3):3738. Available from. https://doi.org/10.1016/.j.jcard.2009.04.037.

11. Gatzoulis MA, Beghetti M, Landzberg MJ, Galiè N. Pulmonary arterial hypertension associated with congenital heart disease: recent advances and future directions. Int J Cardiol. 2014;177(2):340-7. Available from. https://doi. org/10.1016/j.jijcard.2014.09.024.

12. Kempny A, Dimopoulos K, Uebing A, Moceri P, Swan L, Gatzoulis MA, et al. Reference values for exercise limitations among adults with congenital heart disease. Relation to activities of daily life--single Centre experience and review of published data. Eur Heart J. 2012;33(11):1386-96. Available from. https://doi.org/10.1093/eurheartj/ehj461.

13. Authors/Task Force Members, Galiè N, Humbert M, Vachiery J-L, Gibbs S, Lang I, Torbicki A, et al. 2015 ESC/ERS Guidelines for the diagnosis and treatment of pulmonary hypertension: The Joint Task Force for the Diagnosis and Treatment of Pulmonary Hypertension of the European Society of Cardiology (ESC) and the European Respiratory Society (ERS) Endorsed by: Association for European Paediatric and Congenital Cardiology (AEPC), International Society for Heart and Lung Transplantation (ISHLT). Eur 
Heart J. 2016;37(1):67-119. Available from. https://doi.org/10.1093/eurheartj/ ehv317.

14. Fernandes SM, Newburger JW, Lang P, Pearson DD, Feinstein JA, Gauvreau $\mathrm{K}$, et al. Usefulness of epoprostenol therapy in the severely ill adolescent/ adult with Eisenmenger physiology. Am J Cardiol. 2003;91(5):632-5. Available from. https://doi.org/10.1016/50002-9149(02)03328-3.

15. Rosenzweig EB, Kerstein D, Barst RJ. Long-term prostacyclin for pulmonary hypertension with associated congenital heart defects. Circulation. 1999; 99(14):1858-65. Available from. https://doi.org/10.1161/circ.99.14.1858.

16. Thomas IC, Glassner-Kolmin C, Gomberg-Maitland M. Long-term effects of continuous prostacyclin therapy in adults with pulmonary hypertension associated with congenital heart disease. Int J Cardiol. 2013;168(4):4117-21. Available from. https://doi.org/10.1016/.i.jcard.2013.07.072.

17. Lammers AE, Hislop AA, Flynn Y, Haworth SG. Epoprostenol treatment in children with severe pulmonary hypertension. Heart. 2007;93(6):739-43. Available from. https://doi.org/10.1136/hrt.2006.096412.

18. Yang SI, Chung WJ, Jung SH, Choi DY. Effects of inhaled lloprost on congenital heart disease with Eisenmenger syndrome. Pediatr Cardiol. 2012; 33(5):744-8. Available from. https://doi.org/10.1007/s00246-012-0204-0

\section{Publisher's Note}

Springer Nature remains neutral with regard to jurisdictional claims in published maps and institutional affiliations.

Ready to submit your research? Choose BMC and benefit from:

- fast, convenient online submission

- thorough peer review by experienced researchers in your field

- rapid publication on acceptance

- support for research data, including large and complex data types

- gold Open Access which fosters wider collaboration and increased citations

- maximum visibility for your research: over $100 \mathrm{M}$ website views per year

At BMC, research is always in progress.

Learn more biomedcentral.com/submissions 